\title{
Genetic Yield Potential Improvement of Semidwarf Winter Wheat in the Great Plains
}

\author{
Sarah D. Battenfield,^ Arthur R. Klatt, and William R. Raun
}

\begin{abstract}
Recently, private companies and public entities have made significant investments in and improvements to their wheat (Triticum aestivum L.) breeding programs. Because of this increased interest, genetic improvements made in wheat through traditional plant breeding need to be analyzed. Many studies noted the significant yield improvement from tall cultivars to semidwarf cultivars, but no studies have documented improvements made from the earliest semidwarfs to present-day cultivars. Thirty cultivars were tested including two tall (Kharkof, released in 1919, and Triumph 64, released in 1964) and 28 semidwarf cultivars spanning the period from 1971 (TAM 101) to 2008 (Jackpot and TAM 401). Cultivars were tested in 2010 and 2011 at 11 locations across Oklahoma, Kansas, and Texas with fertilizer and fungicide for adequate disease protection. Increases in breeding for yield stability have been made over time. A significant yield increase of 14.607 $\mathrm{kg} \mathrm{ha}^{-1} \mathrm{yr}^{-1}$ or $0.93 \%$ per year of Kharkof yield was obtained across all locations with the tall cultivars included. When gain was restricted to only semidwarf cultivars (1971 to 2008), yield gain was reduced to $11.03 \mathrm{~kg} \mathrm{ha}^{-1} \mathrm{yr}^{-1}$ or $0.40 \%$ per year of TAM 101 (1971) yield. No evidence of a yield plateau was found.
\end{abstract}

S.D. Battenfield, Dep. of Agronomy, 2004 Throckmorton Plant Sci. Center, Kansas State Univ., Manhattan, KS 66506. W.R. Raun and A.R. Klatt, Dep. of Plant and Soil Sciences, 368 Agriculture Hall, Oklahoma State Univ., Stillwater, OK, 74078. Received 6 Mar. 2012. ^Corresponding author (sbatten@ksu.edu).

Abbreviations: NRPN, Northern Regional Performance Nursery; SRPN, Southern Regional Performance Nursery.

$\mathrm{P}$ LANT BREEDING and improved agronomic practices significantly increased wheat yield over time worldwide. The first breeding efforts specific to the Great Plains of the United States began in the 1920s. An introduced land race from Russia known as Turkey or Turkey Red and multiple selections made from this landrace (Cox et al., 1988) were the most popular varieties of wheat in the region at that time. The first purposefully bred varieties in the area were released in the late 1940s. In the 1960s, Dr. Norman Borlaug incorporated semidwarf genes into Mexican spring wheat cultivars producing shorter, higher yielding wheat cultivars, which provided a significant increase in yield. The semidwarf characteristic was incorporated into the Great Plains wheat cultivars by the 1970s. Since that time, incorporation of diverse germplasm with varying genes for pest and disease resistance as well as improved agronomic type has been useful for making yield gains. Additionally, in recent years breeders have had access to genetic marker technologies to enhance their selection of modern wheat cultivars.

Throughout the past century there were significant improvements in agronomic practices. Fertilization methods as well as pesticide, herbicide, and fungicide practices have been extensively studied and given rise to higher yields. Traditionally, genetic improvements were responsible for approximately half of

Published in Crop Sci. 53:946-955 (2013)

doi: 10.2135/cropsci2012.03.0158

(C) Crop Science Society of America 5585 Guilford Rd., Madison, WI 53711 USA

All rights reserved. No part of this periodical may be reproduced or transmitted in any form or by any means, electronic or mechanical, including photocopying, recording, or any information storage and retrieval system, without permission in writing from the publisher. Permission for printing and for reprinting the material contained herein has been obtained by the publisher. 
the yield increases over the past century (Rudd, 2009); however, this must be periodically analyzed. Recently, the private sector has significantly increased investment in wheat breeding. These investments have been made with the intent of possibly releasing transgenic or hybrid wheat within the next 10 to $20 \mathrm{yr}$. Therefore, it is vitally important to quantify yield gains made in wheat due to traditional breeding efforts, especially in the semidwarf era.

Studies of genetic yield potential increase were conducted worldwide and range from 0.44 to $1.3 \%$ increase in yield per year as compared to the oldest cultivar in the study (results summarized in Table 1). However, average improvements are commonly cited as approximately $1 \%$ increase in yield per year of tall landrace variety yield (Rudd, 2009) or less (Fischer and Edmeades, 2010). This linear improvement approximation may be easily skewed with lack of reliable introductory date of landrace varieties and large initial improvements that were made before the release of the first semidwarf cultivars. Beginning with semidwarf cultivars gives us a more realistic rate of increase by using accurate dates of origin for cultivars and introduces gains made in the modern era of wheat breeding.

Analysis of breeding progress can be conducted by studying a set of historical cultivars over multiple locations and years, as was done in this study, or by comparing historical yield data with a standard over time. The two methods of determining increase in genetic yield potential over time each have advantages and disadvantages. Comparing a specified set of historic cultivars over multiple years and locations has been most commonly used worldwide (Cox et al., 1988; Austin et al., 1989; Berzonsky and Lafever, 1993; Sayre et al., 1997; Donmez et al., 2001; Khalil et al., 2002; Brancourt-Hulmel et al., 2003; Zhou et al., 2007; Sener et al., 2009; Morgounov et al., 2010). All tests are conducted in the same site-years, which, if there are enough locations, will reduce environmental bias. This method of testing favors newer varieties that have genetic disease resistance, but experimental design that includes fungicide can negate this bias. Historical yield trials compare the newest germplasm and cultivars but not necessarily farmer adopted varieties. Since these tests are often conducted over wide regional areas, they represent broad yield gains, instead of smaller gains made for specific adaptation. The historic yield trial method relies on the most advanced material compared to a long standing check variety, which has normally lost any resistance it may have once had. Wheat breeders traditionally select for racespecific resistance to pathogens; therefore, this type of trial is often confounded by resistance and susceptibility of the checks and experimental lines. However, this method does allow for the greatest amount of varying materials to be tested and provides statistical stability with the numerous site-years tested (Schmidt and Worrall, 1983; Schmidt, 1984; Graybosch and Peterson, 2010).
Estimation of yield gain using annual data from standardized yield trials has been previously studied in the Great Plains. Schmidt and Worrall (1983), Schmidt (1984), and Graybosch and Peterson (2010) each used the Northern Regional Performance Nursery (NRPN) and Southern Regional Performance Nursery (SRPN) to estimate the gain in genetic yield potential of wheat, using Kharkof as a long-term check variety. The authors reported a rate of genetic gain of approximately $0.74 \%$ of Kharkof per year from 1959 to 1979 (Schmidt and Worrall, 1983; Schmidt, 1984). Graybosch and Peterson (2010) found that between 1959 and 2008 the yield of the SRPN had advanced between 1.1 and $1.3 \%$ of Kharkof yield per year whereas the NRPN yield had only improved 0.79 to $0.85 \%$ of Kharkof yield per year. This methodology also displayed that there were no significant genetic yield progress when only considering cultivars released from 1984 to present. This indicates that in the modern wheat breeding era, yield peaked between 1984 and present, indicating no significant advancements in yield have been made in the period of 1984 to 2008 .

Genetic yield potential in the Great Plains has also been assessed using the multiple cultivars in multiple site-years approach. The baseline study of several cultivars planted simultaneously for this area was conducted from 1985 to 1987 (Cox et al., 1988). The trial was planted in three locations in Kansas over 2 yr and consisted of 35 cultivars without fungicide protection in a randomized complete block design with three replications per location. The authors demonstrated a yield increase of $16.2 \mathrm{~kg} \mathrm{ha}^{-1} \mathrm{yr}^{-1}$ or $1 \%$ of the average yield of the cultivar Turkey per year from 1919 to 1987. Other authors of Great Plains multicultivar, multilocation studies found genetic yield increases ranging from 0.44 to $1.3 \%$ of Turkey yield per year (Donmez et al., 2001; Khalil et al., 2002). The large differences between these three genetic yield potential studies was likely due to different sets of cultivars tested, with less representation available in Donmez et al. (2001) and Khalil et al. (2002). Thus, the Cox et al. (1988) study provided benchmark results from which the current project will compare previous findings and continue to present day cultivars, focusing on the impact of breeding from the semidwarf era forward.

Yield stability, when referring to plant breeding, is often treated as the ability of a cultivar to perform consistently across several environments or various conditions, which is also an indication of genotype $\times$ environment interaction for a cultivar (Pfeiffer and Braun, 1989). For this study, stability was assessed by regressing environment mean yield by cultivar mean yield. Cultivars with low stability would have unpredictable yields in varying environments or not perform well in either low or high input conditions. Goodyielding, high-stability cultivars are often considered to be among the highest yielding, or ranking, within a group of cultivars in both high yield potential and low yield potential environments, have an intercept greater than 0 , and slope 
Table 1. Summary of genetic progress made in many yield trials around the world.

\begin{tabular}{|c|c|c|c|c|c|c|}
\hline Study & Location & Years & Site-years of analysis & $\begin{array}{c}\text { No. of } \\
\text { cultivars }\end{array}$ & $\begin{array}{l}\text { Genetic gain, } \\
\mathrm{kg} \mathrm{ha}^{-1} \mathrm{yr}^{-1}\end{array}$ & $\begin{array}{c}\text { Genetic gain } \\
(\%)^{\dagger}\end{array}$ \\
\hline Austin et al., 1989 & England & $1908-1985$ & 3 & 18 & $\neq$ & 0.81 \\
\hline Berzonsky and Lafever, 1993 & Ohio, United States & 1871-1987 & 16 & 16 & 15.5 & 0.55 \\
\hline Brancourt-Hulmel et al., 2003 & France & $1946-1992$ & 10 & 14 & 49.0 & $\S$ \\
\hline Cox et al., 1988 & Kansas, United States & 1919-1987 & 6 & 35 & 16.2 & 1.00 \\
\hline Donmez et al., 2001 & Kansas, United States & 1919-1996 & 4 & 14 & $\ddagger$ & 0.44 \\
\hline Fufa et al., 2005 & Nebraska, United States & 1874-2000 & 6 & 30 & 10.4 & $\S$ \\
\hline Graybosch and Peterson, 2010 & North Great Plains, United States & 1959-2008 & Approximately $49 \times 21^{\pi}$ & $\#$ & $\ddagger$ & 0.82 \\
\hline Graybosch and Peterson, 2010 & South Great Plains, United States & 1959-2008 & Approximately 49 × 30? & $\#$ & $\ddagger$ & 1.20 \\
\hline Khalil et al., 2002 & Oklahoma, United States & 1919-1997 & 3 & 12 & 18.8 & 1.30 \\
\hline Morgounov et al., 2010 & \multirow{2}{*}{$\begin{array}{l}\text { Siberia, Russia } \\
\text { South Romania }\end{array}$} & 1900-1997 & 7 & 47 & 15.3 & 0.70 \\
\hline Mustăţea and Saulescu, 2011 & & 1993-2005 & 28 & 8 & 36.0 & 0.76 \\
\hline Mustăţea and Saulescu, 2011 & West Romania & 1993-2005 & 12 & 6 & 30.0 & 0.59 \\
\hline Mustăţea and Saulescu, 2011 & East Romania & 1993-2005 & 8 & 6 & 82.0 & 1.53 \\
\hline Sayre et al., 1997 & Mexico & 1962-1988 & 6 & 8 & 67.0 & 0.88 \\
\hline Schmidt and Worrall, 1983 & Great Plains, United States & 1959-1979 & Approximately 20 × 30? & $\#$ & $\ddagger$ & 0.74 \\
\hline Sener et al., 2009 & Turkey & 1976-1999 & 2 & 16 & $\ddagger$ & 0.45 \\
\hline Zhou et al., 2007 & Beijing, China & \multirow{2}{*}{$\begin{array}{l}1969-1999 \\
1964-1995\end{array}$} & 2 & 10 & 64.2 & 1.23 \\
\hline Zhou et al., 2007 & Hebei Province, China & & 2 & 11 & 32.1 & 0.48 \\
\hline Zhou et al., 2007 & Shangdong Province, China & 1960-2000 & 2 & 15 & 32.1 & 0.48 \\
\hline Zhou et al., 2007 & Henan Province, China & 1970-1993 & 2 & 11 & 72.1 & 1.05 \\
\hline
\end{tabular}

tPercentage indicates genetic gain divided by mean yield of oldest cultivar in study.

₹Genetic gain not reported in kilograms per hectare per year.

$\$$ Genetic gain not reported in percent improvement.

"Years $\times$ locations per year

\#Unknown number of cultivars tested due to nature of trial.

of 1 or greater, and good fit to the regression line (Pfeiffer and Braun, 1989). In other words, these cultivars are among the higher yielding varieties in low-input conditions and are responsive to higher inputs. Since stability analyses need many site-years of data, these studies are rarer but can be conducted along with genetic gain studies. All previous yield stability studies (Pfeiffer and Braun, 1989; BrancourtHulmel et al., 2003; Morgounov et al., 2010) found yield stability had increased in their most recent breeding materials. In the present study, individual cultivars were assessed to find cultivars demonstrating highest stability across all trial locations and conditions.

The current study compared 30 Great Plains cultivars over $2 \mathrm{yr}$ at 11 locations per year. The primary purpose of this study was to determine the amount of yield increase due to breeding efforts in winter wheat in Kansas, Oklahoma and Texas from the semidwarf era to the present (1970s to 2008). The most recent cultivars were investigated for evidence of a yield plateau as hypothesized in Graybosch and Peterson (2010). Yield stability was determined and compared among cultivars.

\section{MATERIALS AND METHODS}

\section{Treatments}

Thirty historic cultivars (Table 2) were studied in 2010 and 2011 in 11 locations across Kansas, Oklahoma, and Texas. The cultivars were tested in three replications per location under a split-plot design using fungicide treatment (with or without) as the main plot and cultivar as the subplot. Each cooperator randomized the plots and used plot sizes specified to their own needs, but the design was the same for all locations. With the exception of fungicide treatment, all other agronomic practices were controlled by best practices of individual cooperators.

Trial locations were chosen to be representative of the majority of the wheat growing conditions in the southern Great Plains. Locations studied in Oklahoma were Lahoma, Lake Carl Blackwell, Perkins, Sweetwater (2010 only), and Stillwater (2011 only). Locations studied in Texas were Bushland, Chillicothe, Perryton, and Vernon. Locations studied in Kansas were Conway Springs, Gypsum, and Haven.

Perryton and Bushland represented the Texas High Plains region and probably also represent the Oklahoma panhandle and southwestern Kansas. Perryton was irrigated, but Bushland was not, and both were severely affected by the 2011 drought. Chillicothe and Vernon were chosen to represent the Rolling Plains of Texas. Vernon was irrigated, but Chillicothe was not; both were severely affected by the 2011 drought. Sweetwater represented rainfed wheat in western Oklahoma. Perkins, Stillwater, and Lake Carl Blackwell were chosen because of their varying conditions. Perkins is a dry, sandy location where irrigation was available, but irrigation was not used in 2010. Stillwater has a more uniform soil representative of the eastern wheat belt. Lake Carl Blackwell has a heavy clay soil, which is commonly found in Oklahoma. Lahoma, Conway Springs, and Haven were chosen to be representative of the Oklahoma and Kansas bread basket 
Table 2. List of historic wheat cultivars with year of release, breeding origin, and agronomic type for study in Great Plains genetic yield potential trial (release dates from Cox et al., 1988; Donmez et al., 2001; Khalil et al., 2002; Lone Tree Publishing Company, 2008).

\begin{tabular}{|c|c|c|c|}
\hline Cultivar & Year & Origin & Agronomic type \\
\hline Kharkof & 1919 & Landrace derived from Turkey Red & Tall and awned \\
\hline Triumph 64 & 1964 & Joseph Danne, Oklahoma & Tall and awned \\
\hline TAM 101 & 1971 & Texas A\&M University & Semidwarf and awned \\
\hline TAM 105 & 1979 & Texas A\&M University & Semidwarf and awned \\
\hline Chisholm & 1983 & Oklahoma State University & Semidwarf and awned \\
\hline Weather Master 135 & Mid 1980s & Unknown & Semidwarf and awnless \\
\hline 2180 & 1988 & Pioneer & Semidwarf and awned \\
\hline Longhorn & 1990 & Agri-Pro & Semidwarf and awnless \\
\hline Karl 92 & 1992 & Kansas State University & Semidwarf and awned \\
\hline Ogallala & 1992 & Agri-Pro & Semidwarf and awned \\
\hline Coronado & 1994 & Agri-Pro & Semidwarf and awned \\
\hline Custer & 1994 & Oklahoma State University & Semidwarf and awned \\
\hline Jagger & 1994 & Kansas State University & Semidwarf and awned \\
\hline 2137 & 1995 & Kansas State University & Semidwarf and awned \\
\hline TAM 110 & 1996 & Texas A\&M University & Semidwarf and awned \\
\hline 2174 & 1997 & Oklahoma State University & Semidwarf and awned \\
\hline Jagalene & 2001 & Agri-Pro & Semidwarf and awned \\
\hline Fannin & 2003 & Agri-Pro & Semidwarf and awned \\
\hline Overley & 2003 & Kansas State University & Semidwarf and awned \\
\hline Santa Fe & 2003 & West Bred & Semidwarf and awned \\
\hline TAM 111 & 2003 & Texas A\&M University & Semidwarf and awned \\
\hline Deliver & 2004 & Oklahoma State University & Semidwarf and awnless \\
\hline Endurance & 2004 & Oklahoma State University & Semidwarf and awned \\
\hline TAM 112 & 2004 & Texas A\&M University & Semidwarf and awned \\
\hline Armour & 2006 & West Bred & Semidwarf and awned \\
\hline Duster & 2006 & Oklahoma State University & Semidwarf and awned \\
\hline Fuller & 2006 & Kansas State University & Semidwarf and awned \\
\hline Postrock & 2006 & Agri-Pro & Semidwarf and awned \\
\hline Jackpot & 2008 & Agri-Pro & Semidwarf and awned \\
\hline TAM 401 & 2008 & Texas A\&M University & Semidwarf and awnless \\
\hline
\end{tabular}

where wheat is the main crop. Gypsum was chosen to represent growing conditions in north central Kansas.

The 30 cultivars used were planted on a large acreage in their era and represented popular cultivars in the Great Plains in their respective eras. Kharkof (year of release from Cox et al., 1988) and Triumph 64 were included to show long term advances from tall wheat and where breeding advancements began. Improvements made from 1971 (TAM 101) to 2008 (Jackpot and TAM 401) represent the improvements made during the semidwarf era in the Great Plains. Additionally, four of the cultivars in this were awnless (Table 2).

Before planting, all seeds were treated with tebuconazole (alpha-[2-(4-chlorophenyl)ethyl]-alpha-(1,1-dimethyl-ethyl)1H-1,2,4-triazole-1-ethanol) and metalaxyl (N-(2,6dimethylphenyl)-N-(methoxyacetyl)alanine methyl ester) (Raxil-MD; Bayer Crop Science) at the labeled recommended dosage to prevent seedling diseases. All trials were planted in October and harvested in June, except the Sweetwater (2010) location, which was not harvested until July, resulting in a loss of the awnless cultivars at that location. All plots were harvested mechanically at approximately $12 \%$ moisture. Since the seed for the first year came from various locations and varying time of storage, the amount of seed sown was adjusted to allow for similar number of plants per plot due to differing germination percentage and thousand kernel weights. The second year seed amount was not adjusted because all cultivars were grown in increase plots at one location resulting in similar germination percentage and seed size.

In plots with fungicide treatment, complete season protection was accomplished by applying pyraclostrobin (carbamic acid, [2-[[[1-(4-chlorophenyl)-1H-pyrazol-3-yl]oxy]methyl] phenyl]methoxy-, methyl ester) (Headline; BASF), azoxystrobin (methyl (E)-2-(2-\{[6-(2-cyanophenoxy)pyrimidin4-yloxy\}phenyl)-3-methoxyacrylate) (Quilt; Syngenta), or propiconazole (1-[ [2-(2,4-dichlorophenyl)-4-propyl-1,3-dioxolan-2-yl]methyl]-1,2,4-triazole) (Stratego; Bayer Crop Science) at Feekes 5 or 6 and Feekes 9 at the recommended rates. Plots in Perryton and Sweetwater in 2010 and Bushland in 2011 did not receive fungicide treatment and therefore were treated as a six replication, randomized complete block, no fungicide trial, even though the treatment structure was set as a split plot. The first year of trials was much more severely affected by disease than the second. In 2010, stripe rust (Puccinia striiformis) was present throughout the Great Plains, which is becoming more commonplace. Additionally, leaf rust (Puccinia triticina) and powdery mildew (Blumeria graminis f. sp. tritici) were found in most 2010 plots. Powdery mildew was the main disease present in 2011. Incidences of barley yellow dwarf virus and soilborne 
mosaic virus were found in both years at some sites and were not controlled by the fungicide treatments.

\section{Analysis}

Analyses of variance were conducted for each site-year to determine mean yield, mean square error, and coefficient of variation. Additionally significance of cultivar, fungicide, and the interaction of cultivar and fungicide were determined. The MIXED procedure (SAS Institute, 2003) used to account for split-plot design of each trial (Yang, 2010) was

$$
\text { Model yield = Var Fung Var } \times \text { Fung; Random Rep Var } \times \text { Rep, }
$$

in which Rep is the replication within a single trial, Fung is presence or absence of fungicide treatment, and $V a r$ is the wheat cultivar.

Genetic yield potential was analyzed by linear regression of yield $\left(\mathrm{kg} \mathrm{ha}^{-1}\right)$ by year of cultivar release using the GLM procedure (SAS Institute, 2003). The slope of this regression indicated increase in yield over time. Genetic gain was also represented as percent increase of the earliest benchmark cultivar in the comparison. Separate regression analyses were conducted for all cultivars without fungicide, only semidwarf cultivars without fungicide, all cultivars with fungicide, and semidwarf cultivars with fungicide treatment. Percent gain as a function of Kharkof mean yield was used as the standard gain for all cultivars. Percent gain as a function of TAM 101 mean yield was used as the standard for gain in the semidwarf era because it is the earliest released semidwarf in this study. A linear-plateau model was conducted to determine if genetic gains in yield have plateaued recently.

Yield stability was analyzed by plotting environment mean of specific site-year yield on the $x$ axis and cultivar mean yield on the $y$ axis. Slopes and intercepts were determined for individual cultivars and compared to the average location mean slope for the whole trial. High yield and high stability in stability analysis was considered as $y$ greater than $x$ for all points, and low yield and high stability was considered as $y$ less than $x$ for all points. There was concern that agronomic type might skew genetic potential results, so subsamples of agronomic types were identified. Awnless cultivars were analyzed for differences from cultivars with awns. Tall cultivars were analyzed for differences from semidwarf cultivars. Yield increases among each of the two types were determined by stability differences against the whole.

\section{RESULTS AND DISCUSSION}

\section{Treatments}

Individual plot yields ranged from $6.5 \mathrm{~kg} \mathrm{ha}^{-1}$ for Kharkof in Vernon 2011 to a Duster plot that yielded $5440 \mathrm{~kg} \mathrm{ha}^{-1}$ in Vernon in 2010. Mean yields pooled across all locations, with and without fungicide treatment, displayed the same pattern with the same low- $\left(1503 \mathrm{~kg} \mathrm{ha}^{-1}\right.$ for Kharkof without fungicide and $1638 \mathrm{~kg} \mathrm{ha}^{-1}$ for Kharkof with fungicide) and high-yielding ( $3277 \mathrm{~kg} \mathrm{ha}^{-1}$ for Duster without fungicide and $3578 \mathrm{~kg} \mathrm{ha}^{-1}$ for Duster without fungicide) cultivars (Table 3). Fungicide treatment increased the mean yield of all cultivars. Therefore, at the cultivar level, there was a high impact of the fungicide treatment (Table 3).
Large differences were found between sites and years in this study, as is shown in Table 4. Mean trial yields ranged from $1003 \mathrm{~kg} \mathrm{ha}^{-1}$ at Bushland during 2011 to $3480 \mathrm{~kg} \mathrm{ha}^{-1}$ at Haven during 2010. Trials with fungicide treatment had higher yields on average than those without fungicide treatment in all site-years except the 2011 trials at Chillicothe, Lahoma, Perryton, and Vernon. The locations that responded negatively to fungicide all experienced drought stress during the time of fungicide application, which may have led to yield reducing chemical burns. Fungicide treated plots yielded significantly more than those without fungicide in most locations (Table 4). Fungicide as a main effect was significant, but there was no significant fungicide $\times$ cultivar interaction (data not shown).

Lake Carl Blackwell and Conway Springs in 2011 were excluded from analysis because of excessive variation, as indicated by high coefficient of variation $(\mathrm{CV}>20)$ compared to other site-years. The yield variation in these trials is likely due to drought during the 2011 season. However, other locations with more severe drought pressure did not have the same level of variation.

\section{Stability Analysis}

Semidwarf cultivar means for each location were plotted against the site-year environment mean to determine stability. The slopes of all semidwarf cultivars versus the siteyear environment mean were plotted. Based on these data individual cultivar performance relative to the average of all cultivars in a given yield level was determined (Fig. 1 and 2; Table 3).

Cultivars were described as having high stability if they performed similarly compared to the average at all input levels. Cultivars with high stability were Kharkof, Triumph 64, Chisholm, 2180, Longhorn, Karl 92, TAM 110, 2174, Fannin, Overley, TAM 112, Deliver, Endurance, Fuller, Duster, Postrock, and Jackpot. The cultivars with high stability can be categorized as performing greater than average, approximately equal to average, or below average at all locations. Graphical representations of these three yield levels as compared to average are displayed in Fig. 1.

Farmers prefer cultivars that can yield greater than average in low yield potential environments, representative of bad years, and cultivars that can respond to increased inputs, representative of high inputs in good environmental years. Breeders strive to release cultivars that have good yield in poor conditions, are responsive to high inputs, and are broadly adapted, so they can be planted over a larger acreage. Therefore, cultivars with high stability and average or greater yield at all locations were selected as the best performing cultivars. Of the set of high stability cultivars, 2174, Endurance, Duster, Fuller, Jackpot, Overley, Postrock, and TAM 112 were the only cultivars with high yield and high stability (Fig. 2). These cultivars likely have broad adaptation. Each of 
Table 3. Mean yield performance and standard error of all wheat cultivars with and without fungicide in 2010 and 2011 displayed along with stability intercept, slope, and $R^{2}$ value.

\begin{tabular}{|c|c|c|c|c|c|}
\hline \multirow[b]{2}{*}{ Cultivar } & \multicolumn{4}{|c|}{ Grain yield } & \multirow[b]{2}{*}{ Stability $R^{2}$} \\
\hline & Mean without fungicide & Mean with fungicide treatment & Intercept & Slope & \\
\hline & & $\mathrm{kg} \mathrm{ha}^{-1}$ & & $\mathrm{~kg} \mathrm{ha}^{-1} \mathrm{yr}^{-1}$ & \\
\hline Kharkof & $1503 \pm 202$ & $1638 \pm 204$ & -136.58 & 0.619 & 0.760 \\
\hline Triumph 64 & $2283 \pm 202$ & $2421 \pm 204$ & 88.60 & 0.820 & 0.851 \\
\hline TAM 101 & $2553 \pm 202$ & $2902^{\star \star \star} \pm 204$ & 273.27 & 0.882 & 0.873 \\
\hline TAM 105 & $2541 \pm 202$ & $2954^{\star \star \star} \pm 204$ & 129.85 & 0.940 & 0.871 \\
\hline Chisholm & $2566 \pm 202$ & $2860^{\star * \star} \pm 204$ & -98.77 & 1.013 & 0.831 \\
\hline Weather Master 135 & $2510 \pm 203$ & $2745^{\star \star} \pm 205$ & 266.27 & 0.852 & 0.839 \\
\hline 2180 & $2513 \pm 202$ & $2817^{\star * \star} \pm 204$ & -169.88 & 1.021 & 0.925 \\
\hline Longhorn & $2330 \pm 203$ & $2534^{\star \star} \pm 205$ & -36.69 & 0.890 & 0.845 \\
\hline Karl 92 & $2561 \pm 202$ & $2616 \pm 204$ & -430.17 & 1.097 & 0.855 \\
\hline Ogallala & $2740 \pm 202$ & $2957^{\star \star} \pm 204$ & -82.00 & 1.056 & 0.887 \\
\hline Custer & $2727 \pm 202$ & $2910^{*} \pm 204$ & -279.37 & 1.120 & 0.876 \\
\hline Jagger & $2603 \pm 202$ & $2874^{\star \star} \pm 204$ & 218.23 & 0.909 & 0.938 \\
\hline Coronado & $2579 \pm 202$ & $2798^{\star} \pm 204$ & 85.58 & 0.940 & 0.944 \\
\hline 2137 & $2707 \pm 202$ & $2863^{\star} \pm 204$ & -230.15 & 1.089 & 0.946 \\
\hline TAM 110 & $2749 \pm 202$ & $3127^{\star \star \star} \pm 204$ & -256.87 & 1.150 & 0.882 \\
\hline 2174 & $2818 \pm 202$ & $2945 \pm 204$ & 139.72 & 0.991 & 0.958 \\
\hline Jagalene & $2507 \pm 202$ & $2872^{\star * \star} \pm 204$ & 477.10 & 0.792 & 0.774 \\
\hline Overley & $2713 \pm 202$ & $2924^{\star \star} \pm 204$ & 111.02 & 0.978 & 0.893 \\
\hline TAM 111 & $2793 \pm 202$ & $3095^{\star \star \star} \pm 204$ & -140.90 & 1.112 & 0.909 \\
\hline Fannin & $2547 \pm 202$ & $2717^{\star} \pm 204$ & -101.55 & 0.988 & 0.910 \\
\hline Santa Fe & $2739 \pm 202$ & $2983^{\star \star} \pm 204$ & 108.06 & 0.993 & 0.933 \\
\hline TAM 112 & $2915 \pm 202$ & $3263^{\star \star \star} \pm 204$ & 77.65 & 1.084 & 0.863 \\
\hline Deliver & $2614 \pm 203$ & $2849^{\star \star} \pm 205$ & -175.49 & 1.050 & 0.892 \\
\hline Endurance & $3111 \pm 202$ & $3251 \pm 204$ & 69.55 & 1.124 & 0.920 \\
\hline Fuller & $2866 \pm 202$ & $3032^{\star} \pm 204$ & 202.07 & 0.991 & 0.907 \\
\hline Armour & $3097 \pm 202$ & $3234 \pm 204$ & -236.79 & 1.231 & 0.907 \\
\hline Postrock & $2642 \pm 202$ & $2891^{\star \star} \pm 204$ & 24.45 & 0.989 & 0.956 \\
\hline Duster & $3277 \pm 202$ & $3578^{\star * \star} \pm 204$ & 196.13 & 1.164 & 0.882 \\
\hline Jackpot & $2875 \pm 202$ & $3073^{\star \star} \pm 204$ & 36.40 & 1.058 & 0.912 \\
\hline TAM 401 & $2703 \pm 203$ & $2834 \pm 205$ & -168.22 & 1.062 & 0.936 \\
\hline
\end{tabular}

*Significant at the 0.05 probability level.

**Significant at the 0.01 probability level.

${ }^{* \star \star}$ Significant at the 0.001 probability level.

these cultivars was released in 1997 or later, which seems to indicate an increase in breeding for stability coupled with high yield over time in the Great Plains.

Some cultivars yielded well in low input environments but have poorer performance in high input environments. These cultivars were TAM 101, TAM 105, Weather Master 135, Jagger, Coronado, Jagalene, and Santa Fe. Adversely, some cultivars perform better in higher input environments compared to average and less than average in low input environments; in other words, these cultivars are responsive to added inputs but do not perform well in low input conditions. These cultivars were Ogallala, Custer, TAM 110, TAM 111, Armour, and TAM 401 (Table 3).

\section{Tall and Awnless Cultivars}

Two different agronomic types responded poorly in stability and yield potential compared to the average of all cultivars. Awnless cultivars, Weather Master 135, Longhorn, Deliver, and TAM 401, yielded average or less than average at all yield input levels (Table 3). This is likely due to the trend that hard red winter awnless cultivars are bred with an emphasis for their ability to be used as forage-only cultivars. Tall cultivars, Kharkof and Triumph 64, yielded poorer than average at all input levels (Table 3). This is due to recent breeding efforts to develop semidwarf cultivars with greater harvest index and higher yield potential.

Since these agronomic types displayed lower yield potential, it was hypothesized that they would affect the regression analysis demonstrating overall genetic gain. The exclusion of awnless cultivars from the regression analysis did not significantly alter the results (data not shown). Conversely, tall cultivars did impact the overall yield gain; therefore, separate analyses were conducted where tall cultivars were included and excluded for overall rate of genetic gain. 
Table 4. Site years for wheat genetic yield potential trial with coefficient of variation, mean yields with and without fungicide treatment $\left(\mathrm{kg} \mathrm{ha}^{-1}\right)$, change in yield due to fungicide treatment, and significance of fungicide treatment.

\begin{tabular}{|c|c|c|c|c|c|c|}
\hline \multirow[b]{2}{*}{ Location } & \multirow[b]{2}{*}{ Year } & \multirow[b]{2}{*}{ CV } & \multirow[b]{2}{*}{ Standard error } & \multicolumn{2}{|c|}{ Grain yield } & \multirow[b]{2}{*}{$\begin{array}{c}p \text { value of fungicide } \\
\text { treatment }\end{array}$} \\
\hline & & & & $\begin{array}{l}\text { Mean without } \\
\text { fungicide }\end{array}$ & $\begin{array}{l}\text { Mean with } \\
\text { fungicide }\end{array}$ & \\
\hline & & & & \multicolumn{2}{|c|}{$\mathrm{kg} \mathrm{ha}^{-1}$} & \\
\hline Bushland & 2010 & 5.03 & 34.40 & 2346 & $2396^{*}$ & 0.0426 \\
\hline Chillicothe & 2010 & 8.55 & 66.10 & 3173 & $3440^{\star * *}$ & $<0.0001$ \\
\hline Conway Springs & 2010 & 12.07 & 82.37 & 2970 & $3273^{\star * *}$ & $<0.0001$ \\
\hline Gypsum & 2010 & 7.72 & 52.93 & 2679 & $3078^{* * *}$ & $<0.0001$ \\
\hline Haven & 2010 & 7.79 & 41.79 & 3480 & $4058^{\text {***}}$ & $<0.0001$ \\
\hline Lahoma & 2010 & 11.43 & 57.44 & 1709 & $1936^{\star \star \star}$ & $<0.0001$ \\
\hline Lake Carl Blackwell & 2010 & 10.94 & 80.08 & 3076 & 3142 & 0.2567 \\
\hline Perkins & 2010 & 8.82 & 121.02 & 3944 & $4191^{*}$ & 0.0102 \\
\hline Perryton & 2010 & 4.86 & 17.43 & 3412 & $-^{\dagger}$ & $-^{\dagger}$ \\
\hline Sweetwater & 2010 & 12.71 & 65.58 & 2535 & $-^{\dagger}$ & $-^{\dagger}$ \\
\hline Vernon & 2010 & 13.18 & 65.31 & 2868 & $3880^{\star * \star}$ & $<0.0001$ \\
\hline Bushland & 2011 & 9.80 & 23.61 & 1003 & $-^{\dagger}$ & $-^{\dagger}$ \\
\hline Chillicothe & 2011 & 10.81 & 15.37 & 1002 & 988 & 0.5239 \\
\hline Conway Springs ${ }^{\ddagger}$ & 2011 & 23.52 & & 2102 & 2143 & 0.5834 \\
\hline Gypsum & 2011 & 12.07 & 76.89 & 3289 & 3389 & 0.0735 \\
\hline Haven & 2011 & 8.40 & 43.64 & 3126 & $3475^{\star \star \star *}$ & $<0.0001$ \\
\hline Lahoma & 2011 & 16.23 & 85.61 & 3069 & $2926^{*}$ & 0.0217 \\
\hline Lake Carl Blackwell ${ }^{\ddagger}$ & 2011 & 23.38 & & 1713 & $-^{\dagger}$ & $-^{\dagger}$ \\
\hline Perkins & 2011 & 19.37 & 55.87 & 2367 & $2641^{\star *}$ & 0.0008 \\
\hline Perryton & 2011 & 5.39 & 19.79 & 3416 & 3387 & 0.3140 \\
\hline Stillwater & 2011 & 9.38 & 49.67 & 2939 & $3136^{\star \star \star}$ & $<0.0001$ \\
\hline Vernon & 2011 & 15.26 & 46.60 & 1631 & 1614 & 0.6193 \\
\hline
\end{tabular}

*Significant at the 0.05 probability level.

${ }^{*}$ Significant at the 0.01 probability level.

***Significant at the 0.001 probability level.

${ }^{\dagger}$-, fungicide not applied.

†Excluded from further analyses due to excessive variation.

\section{Genetic Yield Potential}

Genetic yield potential gains were determined by linear regression of yield, expressed in kilograms per hectare, by year of cultivar release. The slope of the regression indicated the increase in yield per year $\left(\mathrm{kg} \mathrm{ha}^{-1} \mathrm{yr}^{-1}\right)$. When all cultivars were pooled over all locations, fungicide treatment was significant, but fungicide $\times$ cultivar interaction was not significant, and fungicide treatment did not significantly change the slope of gain. As a result, mean yield of cultivars with and without fungicide was regressed by year of release

Regression of all cultivars resulted in a genetic yield gain of $14.607 \mathrm{~kg} \mathrm{ha}^{-1} \mathrm{yr}^{-1}$ or $0.93 \%$ of the mean of Kharkof per year (Fig. 3). This yield gain equates to an increase in $1300 \mathrm{~kg} \mathrm{ha}^{-1}$ (19.29 bushels per acre) over $89 \mathrm{yr}$. Since tall cultivars yielded significantly less than semidwarf cultivars and since our objective was to determine the genetic gain in the semidwarf era, analyses were conducted for genetic gain excluding tall varieties. When genetic gain was narrowed to only semidwarf cultivars, or modern breeding efforts, yield gain was reduced to $11.03 \mathrm{~kg} \mathrm{ha}^{-1}$ $\mathrm{yr}^{-1}$ or $0.40 \%$ of TAM 101 yield per year (Fig. 3). The yield gain represented an improvement of $408 \mathrm{~kg} \mathrm{ha}^{-1}$ (6.05 bushels per acre) in the past $37 \mathrm{yr}$.

\section{CONCLUSIONS}

Large variations in yield were found from year to year for some sites and within individual years between sites. These variations were due primarily to differences in soil types, amount of available water, disease conditions, and management practices between sites and available water between years, even in some irrigated sites. In both years, however, Kharkof was the significantly lowest yielding cultivar, and Duster was the significantly highest yielding cultivar. These data show that significant yield gains have been made from the earliest cultivars to modern cultivars under all input levels.

Awnless cultivars consistently performed poorer than their counterparts with awns. The rate of genetic gain is significant but significantly lower than that of the awned semidwarf cultivars if awnless cultivars are analyzed separately for genetic yield increase over time (data not shown). This increase in performance from awnless to awned cultivars may be due to lack of awn photosynthesis that occurs during maturation (Li et al., 2006); however, 


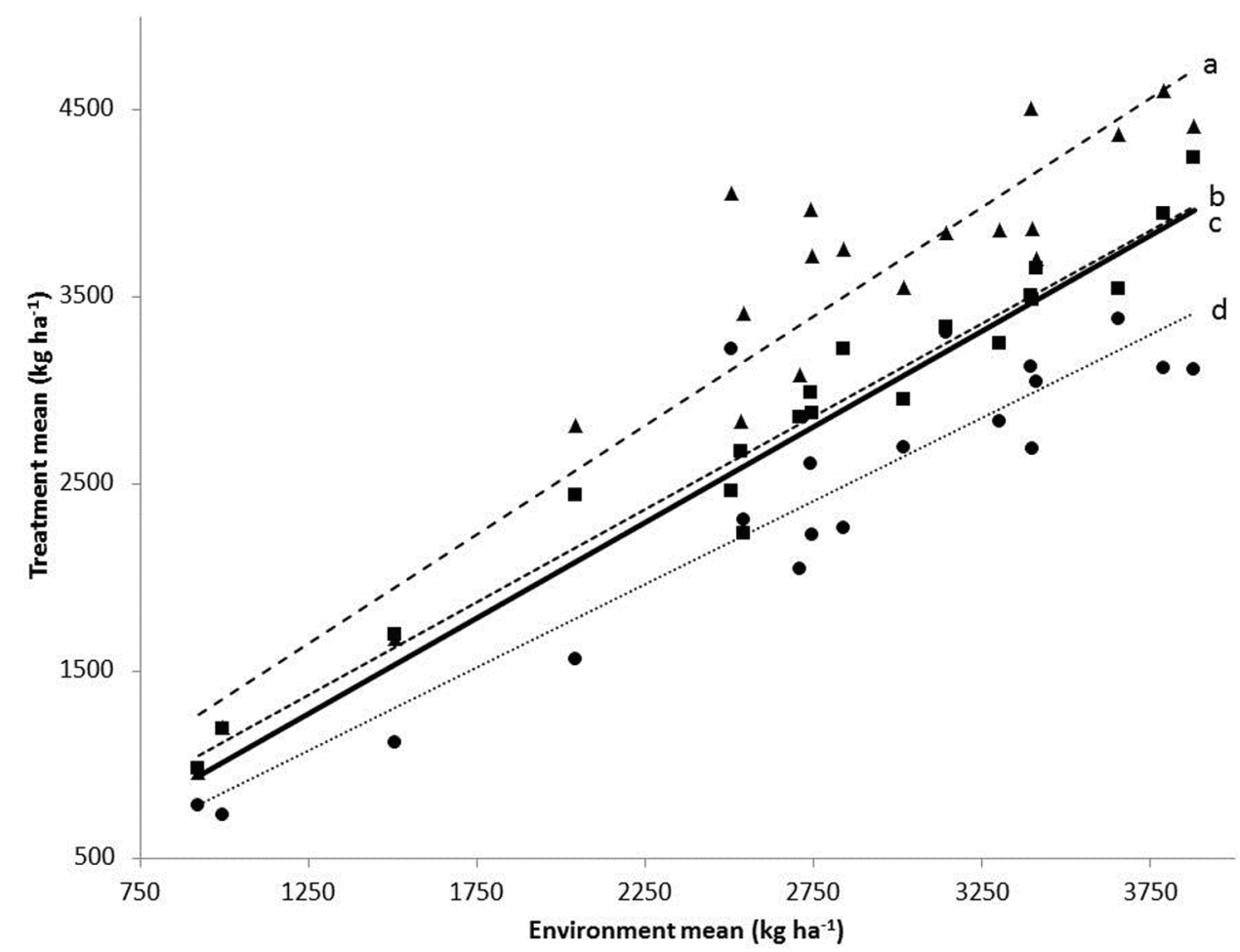

Figure 1. Examples of cultivars with high stability and high yield (Duster; triangle), medium yield (2174; square), and low yield (Longhorn; circle). a) Duster: $y=1.1639 x+196.13, R^{2}=0.8823$; b) $2174: y=0.9914 x+139.72, R^{2}=0.9583$; c) average of all cultivars: $y=x, R^{2}=1$; and d) Longhorn: $y=0.8897 x-36.691, R^{2}=0.8446$.

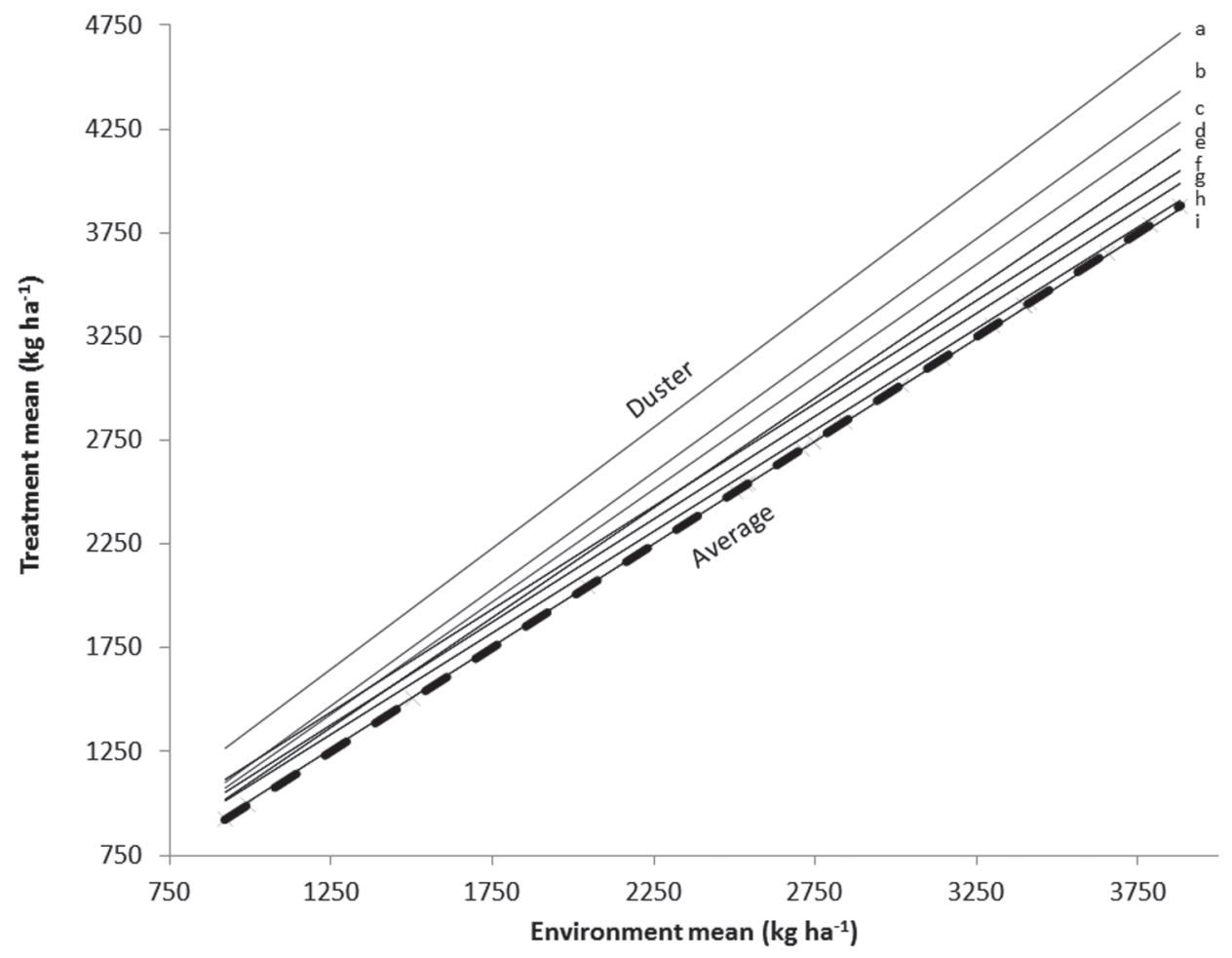

Figure 2. Cultivars with mean yield higher than average at all locations and where slope of regression line is approximately equal to or greater than 1. a) Duster: $y=1.1639 x+196.13, R^{2}=0.8823$; b) Endurance: $y=1.1236 x+69.551, R^{2}=0.9199$; c) TAM 112: $y=1.0839 x$ + 77.647, $R^{2}=0.8632$; d) Jackpot: $y=1.0579 x+46.398, R^{2}=0.9119 ;$ e) Fuller: $y=0.991 x+202.07, R^{2}=0.9066 ;$ f) $2174: y=0.9914 x+$ 139.72, $R^{2}=0.9583$; g) Overley: $y=0.978 x+111.02, R^{2}=0.8934$; h) Postrock: $y=0.989 x+24.454, R^{2}=0.9556$; and i) average of all cultivars: $y=x, R^{2}=1$. 


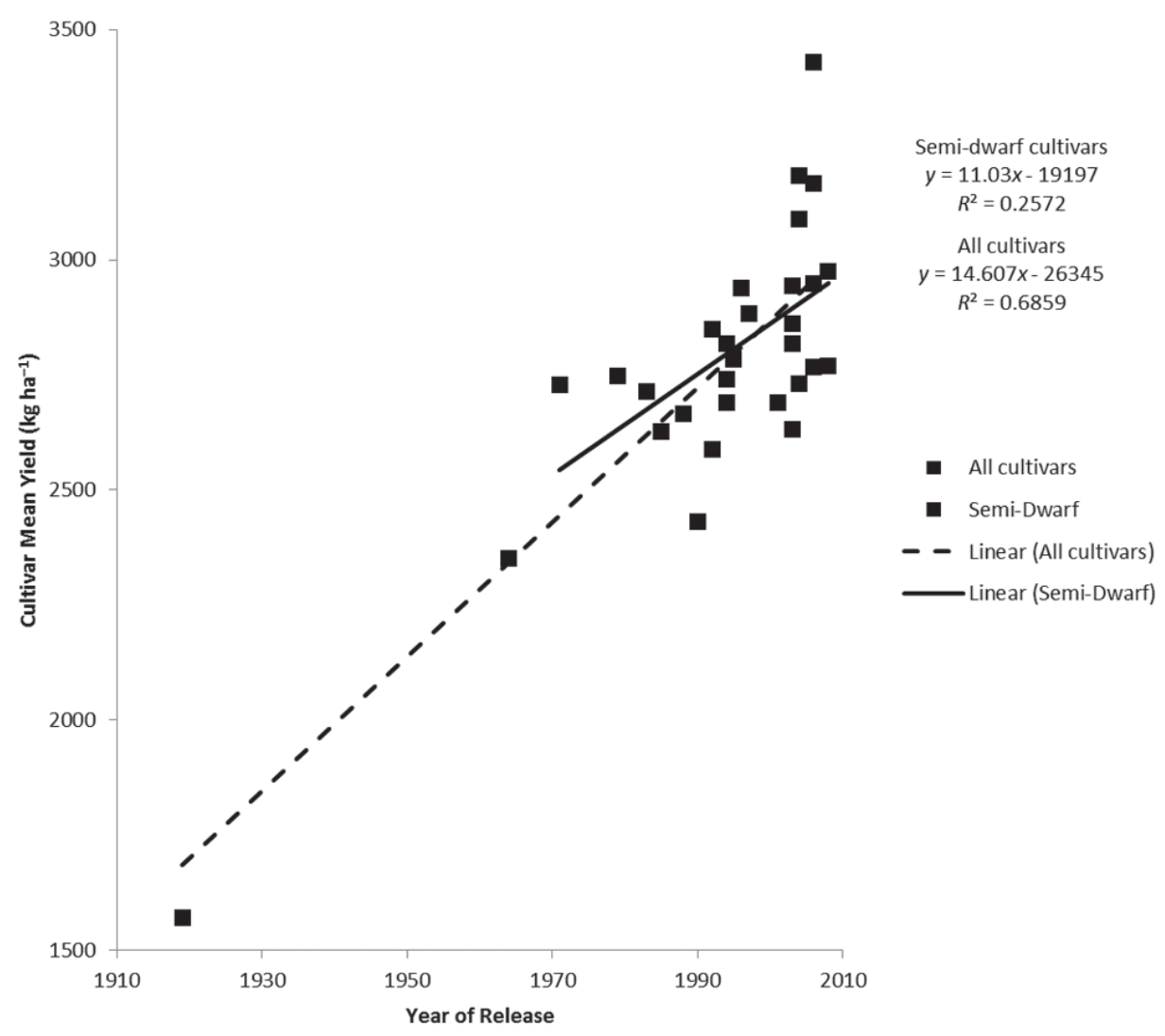

Figure 3. Yield regression of all cultivars by year of release. Regression of yield by year of release including tall cultivars represented in dashed line. Regression of yield by year of release with only semidwarf cultivars represented in solid line.

in other regions and marketing classes of wheat, awnless cultivars are preferred for grain yield potential. Therefore, the yield performance difference is more likely due to breeding resources not being delegated to improving awnless cultivars. This is an effective choice, though, since local producers do not have a preferential interest in using these varieties unless they are completely grazed by cattle.

Genetic yield potential has significantly increased since the initiation of breeding in the Great Plains. The increase in genetic yield potential from Kharkof to present is an increase of approximately 1\% of Kharkof yield per year, which is the statistic that regional breeders commonly quote as the average genetic progress obtained from breeding in this region. However, a significant yield jump and large change in time from the tall varieties to semidwarf varieties presents a distinct new breeding era. Therefore, genetic advances in yield should be presented from the semidwarf era to present and not from the introduction of tall varieties.

Graybosch and Peterson (2010) hypothesized there was a possible yield plateau occurring in recent years, so a linear-plateau model was evaluated to determine if there were two separate responses of yield and year, but no convergence criterion were met. This indicates that a single, linear relationship existed from 1919 to present; however, the semidwarf cultivars and the tall cultivars are biologically different. Also, using TAM 101 as a starting point gives a verifiable start date for the regression of yield.
Semidwarf yield potential increased $406 \mathrm{~kg} \mathrm{ha}^{-1}(6.05$ bushels per acre) over the course of $37 \mathrm{yr}$. Since these gains are from TAM 101 forward, yield gains are expressed in percent yield of TAM 101 per year, not Kharkof. Therefore, the genetic yield gains annually occurring in Great Plains semidwarf cultivars amounts to $0.40 \%$ per year, which is lower than that found among all cultivars including tall cultivars. This change in genetic gain per year excludes the significant increase in yield that was achieved with the introduction of the semidwarf cultivars. Also, these yield gains do not compare to those found in corn or some other crops, most likely because of strict quality standards, and adaptation to adverse environmental conditions that need to be maintained, probably at the expense of yield gains.

\section{Acknowledgments}

Much cooperation was needed for a study of this magnitude. The authors would like to thank Jeff Edwards and Brett Carver of Oklahoma State University, Allan Fritz of Kansas State University, Jackie Rudd and Jason Baker of Texas A\&M University, David Worrall of Agri-Pro, and Sid Perry of WestBred as well as all of their technicians for their immense assistance in this project with the trials they conducted. Acknowledgments should be made to William Raun and Jose Crossa for statistical consult in this project. The authors graciously acknowledge Oklahoma Wheat Research Foundation, Oklahoma Wheat Commission, and Oklahoma State University for funding this research. 


\section{References}

Austin, R.B., M.A. Ford, and C.L. Morgan. 1989. Genetic improvement in the yield of winter wheat: A further evaluation. J. Agric. Sci. 112:295-301. doi:10.1017/S0021859600085749

Berzonsky, W.A., and H.N. Lafever. 1993. Progress in Ohio soft red winter wheat breeding: Grain yield and agronomic traits of cultivars released from 1871 to 1987. Crop Sci. 33:13821386. doi:10.2135/cropsci1993.0011183X003300060050x

Brancourt-Hulmel, M., G. Doussinault, C. Lecomte, P. Berard, B. Le Buanec, and M. Trottet. 2003. Genetic improvement of agronomic traits of winter wheat cultivars released in France from 1946 to 1992. Crop Sci. 43:37-45. doi:10.2135/ cropsci2003.0037

Cox, T.S., J.P. Shroyer, L. Ben-Hui, R.G. Sears, and T.J. Martin. 1988. Genetic improvement in agronomic traits of hard red winter wheat cultivars from 1919 to 1987. Crop Sci. 28:756760. doi:10.2135/cropsci1988.0011183X002800050006x

Donmez, E., R.G. Sears, J.P. Shroyer, and G.M. Paulsen. 2001. Genetic gain in yield attributes of winter wheat in the Great Plains. Crop Sci. 41:1412-1419. doi:10.2135/ cropsci2001.4151412x

Fischer, R.A., and G.O. Edmeades. 2010. Breeding and cereal yield progress. Crop Sci. 50:S-85-S-98. doi:10.2135/ cropsci2009.10.0564

Fufa, H., P.S. Baenziger, B.S. Beecher, R.A. Graybosch, K.M. Eskridge, and L.A. Nelson. 2005. Genetic improvement trends in agronomic performances and end-use quality characteristics among hard red winter wheat cultivars in Nebraska. Euphytica 144:187-198. doi:10.1007/s10681-005-5811-x

Graybosch, R.A., and C.J. Peterson. 2010. Genetic improvement in winter wheat yields in the Great Plains of North America, 1959-2008. Crop Sci. 50:1882-1890. doi:10.2135/ cropsci2009.11.0685

Khalil, I.H., B.F. Carver, E.G. Krenzer, C.T. MacKown, and G.W. Horn. 2002. Genetic trends in winter wheat yield and test weight under dual-purpose and grain-only management systems. Crop Sci. 42:710-715. doi:10.2135/cropsci2002.0710

Li, X., H. Wang, H. Li, L. Zhang, N. Teng, Q. Lin, J. Wang, T. Kuang, Z. Li, B. Li, A. Zhang, and J. Lin. 2006. Awns play a dominant role in carbohydrate production during the grain-filling stages in wheat (Triticum aestivum). Physiol. Plant. 127:701-709. doi:10.1111/j.1399-3054.2006.00679.x

Lone Tree Publishing Company. 2008. Wheat varieties list. Lone Tree Publishing Co. LC, Topeka, KS. http://thewheatfarmer. com/varieties_info.shtm (accessed 1 Aug. 2011).
Morgounov, A., V. Zykin, I. Belan, L. Roseeva, Y. Zelenskiy, H.F. Gomez-Becerra, H. Budak, and F. Bekes. 2010. Genetic gains for grain yield in high latitude spring wheat grown in Western Siberia in 1900-2008. Field Crops Res. 117:101-112. doi:10.1016/j.fcr.2010.02.001

Mustățea, P., and N.N. Saulescu. 2011. Estimation of genetic trends in yield and agronomic traits of recent Romanian winter wheat (Triticum aestivum, L.) cultivars, using direct comparisons in multiyear, multi-location trials. Romanian Agric. Res. 28:17-24.

Pfeiffer, W.H., and H.J. Braun. 1989. Yield stability in bread wheat. In: J.R. Anderson and P.B.R. Hazell, editors, Variability in grain yields. John Hopkins Univ. Press, Baltimore, MD. p. 157-174.

Rudd, J.C. 2009. Success in wheat improvement. In: B.F. Carver, editor, Wheat: Science and trade. Wiley-Blackwell, Ames, IA. p. 387-395.

SAS Institute. 2003. 9.1 Foundation for 64-bit Microsoft Windows. SAS Inst., Cary, NC.

Sayre, K.D., S. Rajaram, and R.A. Fischer. 1997. Yield potential progress in short bread wheats in Northwest Mexico. Crop Sci. 37:36-42. doi:10.2135/cropsci1997.0011183X003700010006x

Schmidt, J.W. 1984. Genetic contributions to yield gains in wheat. In: W.R. Fehr, editor, Genetic contributions to yield gains of five major crop plants. CSSA Spec. Publ. 7. ASA and CSSA, Madison, WI. p. 89-101.

Schmidt, J.W., and W.D. Worrall. 1983. Trends in yield improvement through genetic gains. In: Proceedings of the 6th International Wheat Genetics Symposium, Kyoto, Japan. 28 Nov. to 3 Dec. 1983. Plant Germ-Plasm Institute, Faculty of Agriculture, Kyoto University, Kyoto, Japan. p. 691-700.

Sener, O., M. Arslan, Y. Soysal, and M. Erayman. 2009. Estimates of relative yield potential and genetic improvement of wheat cultivars in the Mediterranean region. J. Agric. Sci. 147:323332. doi:10.1017/S0021859609008454

Yang, R. 2010. Towards understanding and use of mixed-model analysis of agricultural experiments. Can. J. Plant Sci. 90:605627. doi:10.4141/CJPS10049

Zhou, Y., Z.H. He, X.X. Sui, X.C. Xia, X.K. Zhang, and G.S. Zhang. 2007. Genetic improvement of grain yield and associated traits in the northern China winter wheat region from 1960 to 2000. Crop Sci. 47:245-253. doi:10.2135/ cropsci2006.03.0175 